\title{
Body Odor, CTCAE
}

National Cancer Institute

\section{Source}

National Cancer Institute. Body Odor, CT CAE. NCI Thesaurus. Code C143330.

A disorder characterized by an abnormal body smell resulting from the growth of bacteria on the body. 